УДК 340 (477)

DOI https:/ / doi.org/10.32837/yuv.v0i4.1002

А. Кожевнікова,

аспірантка кафедри теорії, історії держави і права та конституційного права

Навчально-наукового інституту права

Університету державної фіскальної служби України

\title{
РОСІЙСЬКО-УКРАЇНСЬКІЙ КОНФЛІКТ. КОНФЛІКТ І КОМПРОМІС У ПРАВІ
}

Сьогодні подальшій розвиток подій на Україні визначається як компромісний сценарій російсько-українського конфлікту. Для вирішення цієї дуже важливої міжнародної проблеми необхідно, насамперед, визначити поняття та специфіку особливості інтерпретації конфлікту і компромісу та аналізу розвитку вчень про конфлікт і компроміс.

Конфлікти займають одне 3 центральних місць серед типів соціальної взаємодії та міжнародних відносин, які потребують досконалого вивчення.

Насамперед, найбільш повно пізнати правовий конфлікт та правовий компроміс можна на державному рівні організації соціуму.

Держава є вищим рівнем організаціï соціуму, у межах якого розкриваються всі сутнісні характеристики компромісу i конфлікту. Поясняється це тим, що: по-перше, динаміка конфлікту і компромісу здійснюється у соціально-неоднорідному суспільстві та забезпечується функціонуванням механізму держави; по-друге, природа компромісу і конфлікту розкривається у двох сенсах - широкому (відповідний стан функціонування державно-організованого суспільства) та вузькому (засіб порушення соціальних норм, усунення правових колізій і подолання прогалин у праві); по-третє, генезис конфліктів і компромісів зумовлюється професіоналізацією ї учасників у межах держави.

Зважаючи на наведе, розглянемо основні ідеї мислителів щодо правового конфлікту та правого компромісу на державному рівні, починаючи від Стародавнього Китаю і Стародавньої Індії та закінчуючи поглядами мислителів XIX - початку XX ст.

Провідний китайський філософ Конфуцій (551-479 рр. до н. е.) і його послідовники були прихильниками родоієрархічної політичної системи держави, що породжувало війну класів i, як правило, приводило до знешкодження середнього класу [5, с. 27-39]. Результатом такої соціальної моделі суспільства $€$ незгасаючі конфлікти. Функціонування конфліктів має не статичний характер, а постійний динамічний характер. Таким чином, у суспільстві домінує режим конфліктності, зумовлений постійними протиріччями між членами такого суспільства, зокрема держави, а також між державами.

У конфуціанстві виводять так звану етику «золотої середини», зміст якої полягає в обов'язку кожного члена суспільства жити в злагоді 3 іншими людьми. На думку Конфуція, названа етика базується на правлінні «аристократів доброчесності та знання», а не «родинного панства та багатіїв». Правитель повинен дотримуватись принципів доброчинності у державному управлінні та забезпечувати рівномірний розподіл багатств [11, с. 32-34]. Така теоретична позиція конфуціанства відрізнялась від фактичного стану справ у державно-політичній системі Стародавнього Китаю, в якій переважали засоби деспотичного насильства над підданими i антиморалістична поведінка в політиці. 


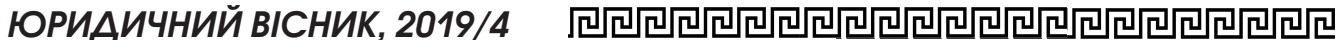

Узагальнюючи різнобічні ідеї Конфуція, можна стверджувати, що, незважаючи на закладену в них класову боротьбу, вони у кінцевому підсумку спрямовані на примирення суспільства та компромісний характер його життедіяльності. Підставою для такого висновку є принцип «хе», який означає єднання та злагоду шляхом протиборства. За словами Конфуція, повноцінне політико-правове рішення можливе лише на засадах врахування різноманітних думок та взаємних поступок. Подібно до того як майстер-кухар готує смачну страву, наповнену інгредієнтами, що мають суперечливі смакові якості (солоні овочі й солодкі фрукти), так i необхідне рішення приймається у процесі протиборства, поступок, шляхом сполучення «П'яти смаків», «П'яти звуків», «П'яти запахів», тощо [5, с. 34-38]

Необхідно також зазначити, що у конфуціанстві має перевагу природно-правовій підхід до пізнання конфлікту і компромісу. Пов'язано це 3 тим, що норми доброчинності, моральності (лі, шу, чхун, джень) протиставляються нормам позитивного закону (фа), які, у свою чергу, характеризуються надмірною жорстокістю та цинізмом [5, с. 53-65].

Інший представник китайської філософіï Лао-цзи (VI ст. до н. е.), який також є прихильником природно-правого підходу до пізнання конфлікту і компромісу, називає умовою ефективного функціонування держави та іiі правової системи узгодженість усіх класів на підставі принципу «недіяння» і застосування засобів переконання замість засобів примусу. Лао-цзи стверджує, що якщо застосовується сила, навіть зумовлена нормами права, тоді виникають найбільш гострі конфлікти. Примушення людей робити щось за вашою волею, що грунтується на певних правових приписах, не приведе їх до наявності та розуміння встановлених правил, а, навпаки, буде породжувати ще більшу соціальну конфліктність. Розумний правитель застосовує силу лише у тому разі, коли всі інші засоби біли вичерпані [6, с. 21].

Однак, деякі представники легізму, наприклад Хай Фей (III ст. до н. е.) [12, с. 210-215], висловлювали позицію щодо наявності інших регулятивних засад, окрім примусу та зміни законів у зв'язку з плином часу. Щодо цього вони були певними передвісниками ідей класичного нормативізму та історичної школи права. ІІх підхід у межах філософіï легізму надає можливість говорити про наявність правової конфліктності, зокрема колізіі правових норм і вирішення цих колізій за допомогою правокомпромісних засобів. Історичну недосконалість закону допомагає зазначити система «рінгі», яка полягає у встановленні певних норм шляхом проведення опитування групи людей або населення. Правильність такого підходу підтверджується його історичною живучістю. Наприклад, система «рінгі» знайшла своє відображення у сучасному японському менеджменті. Більшість японських компаній приймають важливі економічні рішення тільки після багатократного вивчення різноманітними співробітниками проблеми та умов ї̈ виникнення $з$ подальшим обміном думками та загальним обговоренням шляхів вирішення такої проблеми [19, с. 18-20]. За аналогією систему «рігі» можна порівняти 3 таким сучасним вітчизняним інститутом конституційного права, як референдум, зокрема консультативний.

В індійській філософії дослідження правого конфлікту і правого компромісу базується на майже схожих типах правого пізнання таких як теологічно-традиційний, природно-правовий (частково антропологічний) і нормативістьський (частково етатистський).

Теологічно-традиційна концепція пізнання правого конфлікту і компромісу знайшла своє відображення у первинних джерелах індійської філософії [13, с. 54-59], таких як Веди (II тис. до н. е.), Упанішади (IX-VI ст. до н. е), Закони Ману (II ст. до н. е.) тощо.

Основною класовою групою у межах цієї концепції є брахмани (жерці), які

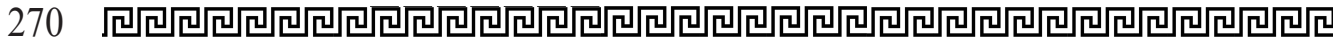


здійснюють тлумачення та забезпечення дхарми (божественно встановлених правил поведінки). Закріплення такого суспільного ладу на рівні правових норм вже на статичному рівні життєдіяльності суспільства встановлювало певний режим конфліктності. Окрім того, чинником посилення конфліктного стану суспільства, зокрема правої реальності, була легалізація данданіті (мистецтва управління за допомогою покарання). Покарання також як і у представників Китайської філософії легізму застосовувалось на принципах нерівності та непропорційності його міри скоєному правопорушенню.

Отже, у межах такого підходу на рівні законів затверджується насильницький консенсус та конфлікт, функціонування яких майже унеможливлює будь-які виявлення правого компромісу. Пов'язано це з тим, що авторитарна група брахманів узурпує владу і встановлює як писані, так і неписані антиправові закони. Тобто, будь-яка поведінка, яка не відповідала чинним теологічним правилам та встановленим на їх основі законам, була протиправною і долалась за допомогою насильства (насильницького консенсусу).

Ці ідеї зазнавали критики і яскравим представником природно-правової концепції дослідження конфліктів і компромісів у Стародавній Індіï був філософ Сіддхартха, він же Будда (VI ст. до н. е.). Будда заклав антропологічні засади пізнання правових явищ. Так, наприклад, за його словами тільки людська поведінка є першоджерелом суспільних законів [17, с. 113-118].

Будда критикував ідеї теологічно-традиційної концепції пізнання правових явищ і стверджував, що не існує законів, наданих Богом. Закони $€$ природним явищем, яке функціонує як незалежний об'єктивний елемент. Звідси він розрізняв природні та суспільні закони. Щоб запровадити суспільні закони, людина спочатку повинна пізнати природні закони, що потребує відповідних знань, а також моралістичних та розумових зусиль.
Будда заклав засади природно-правової концепції правопізнання, а також розвинув ідеї антропологічного розуміння права, які базувались на засадах індивідуальної діяльності, результатом якої повинно стати досягнення нірвани (стану найвищого просвітлення).

Таким чином, Будда висловлював думку щодо обмеження ролі і масштабів насильства, а насильницький консенсус він виключав взагалі як неможливе явище у середовищі, і тільки природні закони мають силу. Пізнання людиною природних законів дає їй можливість діяти на засадах компромісу, навіть під час виникнення конфліктних ситуацій. Слід зазначити, що філософський підхід Будди до пізнання природних явищ розроблявся для невеликої групи осіб, які повинні були тлумачити природні закони для підвищення рівня суспільного існування. Отже, Будда був основоположником професійної групи, яка нині іменується юристами, він заклав основоположні засади презумпції невинуватості у частині неможливості застосування покарання без наявності у суб'єкта вини.

Зважаючи на наведене, ідеї Будди слугували історичним підгрунтям для формування засад демократичної держави, в якій домінує режим компромісності, а державні конфлікти, як і міжнародні, регулюються за допомогою правокомпромісних засобів.

Слід зазначити також, що західноєвропейські та американські дослідження правового конфлікту і правового компромісу були засадою формування у $\mathrm{XX}$ ст. теорій правопізнання цих юридичних явищ, а також були використані у працях українських просвітників XIX - початку XX ст., зокрема М. П. Драгоманова (1814-1895 рр.), Лесі Українки (1871-1913 рр.), I. Я. Франка (1856-1916 рp.), Т. Г. Шевченка (1814-1861 рр.) та ін.

Таким чином, за допомогою аналізу та синтезу наукових ідей західноєвропейських та американських мислителів нового часу вперше у вітчизняній юриспруденції було сформульовано прин- 
ципи правового конфлікту і правового компромісу, до яких віднесено:

- принцип правової рівності, заснований на справедливості, при застосуванні правокомпромісних засобів (I. Кант, Дж. Локк);

- принцип об'єктивації форми та змісту правового конфлікту (Гегель, Т. Джефферсон);

- принцип врахування позиції меншості й дотримання процедури загального виявлення більшістю голосів (Гегель, Ш. Монтеск'є, Ж.-Ж. Руссо).

Наведені принципи слід законодавчо закріпити (з корекцією на сьогодення) 3 метою ефективного упорядкування правових конфліктів правокомпромісними засобами, а також використовувати їх при вирішенні міжнародних конфліктів.

Сучасний стан законодавства в Україні, яке орієнтовано на забезпечення прав та свобод людини i при цьому у більшості випадків не має моралістичної основи реалізації своїх положень, $є$ прикладом зазначених протиріч. Так, існує велика кількість прикладів поведінки, яка прямо не заборонена законом, і їі можна вважати правовою, але іï зміст та цільова спрямованість вступає в протиріччя із сенсом та духом права, нормами моралі та моральності. Прикладом цього є спроби деяких політичних сил в Україні, використовуючи нечітке визначення в основному Законі конституційного ладу України, тлумачити його на свій розсуд.

Отже, тепер необхідно з'ясувати сутність правих конфліктів і правових компромісів у міжнародній складовій правотворчості України до яких можна віднести:

- міжнародні договори і угоди, учасниками яких є Україна (угоди, конвенції, хартіі);

- рішення міжнародних судових інституцій;

- міжнародні звичаї (традиціі), які Україна визнає як загальнообов'язкові регулятори суспільних відносин.

Варто наголосити на тому, що російсько-український конфлікт пов' язаний із укладенням Закону України «Про ратифікацію Європейської хартії регіональних мов або мов меншин» від 15 травня 2003 р. № 802-IV. Передбачено, що положення Хартії застосовуються до визначеної кількості мов національних меншин. Так, у Законі імперативно визначено, що Хартія, як міжнародний договір, поширюється лише на 13 мов національних меншин (білоруську, болгарську, гагаузьку, грецьку, єврейську, кримськотатарську, молдавську, німецьку, польську. російську, румунську, словацьку та угорську).

Про наявність внутрішнього правового конфлікту в частині відповідності національного законодавства положенням Європейської Хартії регіональних мов або мов меншин свідчить також і те, що положення ст. 10 Конституції України не надають розгорнутої відповіді на питання про порядок використання державної та інших мов на території України, а передбачають, що закон має визначати застосування мов в Україні.

Отже, недосконалість національного законодавства, його неузгодженість з низкою положень Хартії призводять до формування внутрішнього правого конфлікту, зокрема між положенням Хартії та ст. 10 Конституції України.

Таким чином, існує необхідність такого правокомпромісного засобу, як тлумачення Конституційним Судом України ратифікованих положень Хартії та визначення їх відповідності ст. 10 Конституції України.

Також, дуже важливо застосовувати правокомпромісний засіб при виконанні Мінських угод та підписанні інших документів для врегулювання російсько-українського конфлікту.

На підставі вищезазначеного можна констатувати, що комплекс компромісних засобів побудований на принципах взаєморозуміння, взаємопоступки, толерантності, допустимості, обгрунтованості, нормах моралі і моральності, здійснюється за встановленою процедурою, наприклад, в юридичній практиці така процедура здійснюється 
відповідно до правових приписів нормативно-правових актів.

Практика прогнозування й розв'язування конфліктів говорить про те, що найчастіше конфлікти виникають і розгортаються 3 причин власне когнітивних. Люди, більшою мірою, погано собі уявляють, які психологічні причини виникнення конфліктів, які стани людей у конфлікті, особливості поведінки і спілкування, яка динаміка конфліктів, що стоїть за стратегіями i тактиками конфліктної протидії. Це незнання тільки провокує протиріччя, стихійні інциденти, заважає конструктивному розв'язанню конфліктів. Іншими словами, однією з найважливіших психологічних причин конфліктів $€$ нестача або недостатній розвиток конфліктологічної компетентності. Ця причина $€$ надзвичайно поширеною і ї̈ потрібно обов'язково вивчати також як і політичні конфлікти, основними суб'єктами яких виступають держави, міжнародні політичні спілки, політичні партії тощо, щоб можливо було провадити превентивні міри, а також з метою профілактики конфліктів.

Слід зазначити, що держава, як i будь-який соціальний інститут, не $€$ досконалою формою організації соціуму. Конфлікти постійно виникають у ї̈ межах і за ії межами, що пов'язано із конфліктністю самої людини. Водночас у державі, на відміну від інших соціальних інститутів, механізм подолання має системну побудову, основними елементами якої $є$ компроміс і консенсус $[14$, с. 112]. За словами Б. А. Толчинського, у демократичній правовій системі компроміс є основним засобом забезпечення прав та свобод людини i громадянина, а також стабільності та миру.

На сьогодні Україна все ще перебуває на стадії політичного та економічного становлення. Це призводить до того, що Українська держава має відносно обмежені можливості для контролю за суспільною думкою та відповідними соціальними процесами. Вона не може поки ще виявити чітку наці- ональну позицію у прийнятті рішень, що зумовлено постійними політичними кризами, відсутністю правлячого центру та підтримки з боку населення, а також відповідними правовими прогалинами. Все це дає можливості будьякій державі розв'язувати конфліктні ситуації на іï території.

Отже, необхідно продовжувати дане дослідження та аналізувати перспективи подальших розробок у цьому напрямі, оскільки це сприятиме гармонізації людських відносин, відносин на державному рівні і на рівні міжнародних відносин для врегулювання та мирного вирішення російсько-українського конфлікту.

У статті розглядається проблема співвідношення права та конфліктологіi, компромісів та колізій у законодавстві для вирішення російсько-українського конфлікту.

Сьогодні, як уже було помічено, Україна знову переживає боротьбу за свою незалежність, а передові знання в ијій галузі є дуже важливими зараз $і$ для майбутнього.

Сьогодні подальші подіï в Україні визначаються як компромісний сизенарій російсько-українського конфлікту. Для вирішення иієї дуже важливої міжнародної проблеми необхідно, пери за все, визначити поняття та специфіку особливостей інтерпретації конфлікту та компромісу та аналізу розробки доктрин щзодо конфлікту та компроміcy.

Конфлікти є иеетрральними для типів соиіальної взаємодії та міжнародних відносин, які потребують ретельного вивчення.

Перш за все, найповніше знання юридичного конфлікту та правового компромісу можливе на державному рівні організації суспільства.

Держава - иее найвищий рівень організаціі суспільства, в межах якого розкриваються всі істотні характеристики компромісу та конфлікmy. 


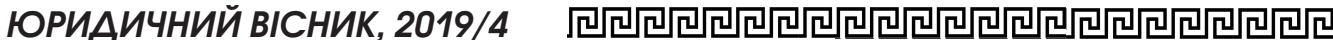

Так, автор подав рекомендаціі щодо необхідності розробки науковоі дискусї з питань конфлікту та компромісів у праві з метою обтрунтування шляхів удосконалення сучасного права.

Ключові слова: конфлікт, міжнародний конфлікт, компроміс, психологія конфлікту, російсько-українській конфлікт, правокомпромісний засіб, легізм, рінгі.

\section{Kozhevnikova A. RUSSIA- UKRAINE CONFLICT. CONFLICT AND COMPROMISE IN LAW}

The paper is given by the problem of the relation between law and conflictology, compromises and conflicts in law to resolve the RussianUkrainian conflict.

Nowadays as it has been already noticed Ukraine is once again experiencing the struggle for its independence and advanced knowledge in this field is very important now and for the future.

Today, further developments in Ukraine are defined as a compromise scenario for the Russian-Ukrainian conflict. In order to solve this very important international problem, it is necessary, first of all, to define the notion and specificity of the peculiarities of the interpretation of the conflict and the compromise and the analysis of the development of the doctrines on the conflict and the compromise.

Conflicts are central to the types of social interaction and international relations that require thorough study.

First of all, the most complete knowledge of legal conflict and legal compromise is possible at the state level of the organization of the society.

The state is the highest level of organization of society, within which all the essential characteristics of compromise and conflict are revealed.

So, the author provided recommendations of the the need to develop a scientific debate on the issues of conflict and compromise in law in order to justify ways of improving modern law.

Key words: conflict, international conflict, compromise, psychology of conflict, Russia-Ukraine conflict, legal compromise means, legalism, ringi.

\section{Література}

1. Артхашастра или «Наука политики» / [пер. с санскрита] ; изд. Поде. В. И. Кальянов. - М. : Науч.-изд. Центр «Ладомир»: Наука, 1993.- 793 с.

2. Емельянов С. М. Практикум по конфликтологии. - СПб: Питер, 2000.

3. Зазыкин В. Г. Конфликтологическая компетентность как фактор профессионализма госслужащих / / Российское государство и государственная служба на современном этапе. - М., 1999.

4. Зеркин Д. П. Основы конфликтологии. - Ростов-н/Д: Феникс, 1998.

5. История политических и правовых учений : [учеб. для вузов] / под общ. ред. Члена-корреспондента РАН В. С. Нерсесяна. - M., 1996. - 440 c.

6. Лао Дзы. Дао лидера / изложен. Джона Хейдера. - М. : Медков С. Б., 2007. - 171 c.

7. Лисищьн Д. В. Теория общественного договора Т. Гоббса и Дж. Локка как предпосылка возникновения современной модели конституционализма / / Российская юридическая наука на этапе формирования правого государства (Межвузовский сборник научных статей (по материалам научно-практического семинара). - М. : Академия права и управления, 2003. - С. 119-131.

8. Шан Ян. Книга правителя области Шан. - /2-е изд./ / /nер. с кит.: вступ. ст., коммент., послесл. Л. С.Переломова) - М.: НИЦ «Ладомир», 1993. - 392 с.

9. Обозов Н. Н. Психология конфликта и способы его разрешения.- Л.: Центр прикладной психологии, 1991.- 45 с.

10. Пащук Т. I. Юридични засоби захисту прав людини: поняття та види // Держава і право : зб. наук. пращь : Юридичні i політичні. - 205. - № 28. C. $48-56$.

11. Переломов Л. С. Конфуций: жизнь, учение, судьба. - М. : Наука : Восточная ruтература, 1993. - 440 c.

12. Переломов Л. С. Конфуцианство и легизм в политической истории Китая. M. : Наука, 1981. - 333 c. 


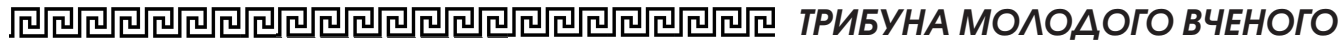

13. Рогозина 3. А. История Индии времен Puг-Beдbl : coчurerue. - Cnб . : Tun.лит. А.Ф. Марк, 1905. - 496 с

14. Толчинский Б. А. Политический компромис: современная проблематика // Государство и право.1992._№ 12.- C.85-92.

15. Цимбалюк М. Громадянське суспільство як фактор утвердження демократичної правосвідомості / М. Цимбалюк / / Право Укаӥни. - 2007. - № 11. С. 21-25.

16. Хасан Б. И. Психотехника конфликта и конфликтная компетентность. - Красноярск, 1996.
17.Чопра Дипак. Будда: история просветления / Дипак Чопра ; /пер. с англ. A. Крылова]. - СПб. : Мидгард, 2008. 349 c

18. Юридична конфліктологія /Под. ред. В. Н. Кудрявиева.- М.: Юрсит. 1997.

19. Эти невероятные япониы: приниипь японского управления / K. Паркинсон, М. K. Ростомджи, C. A. Canpe, и др. : [пер. В. Вархушева], - M. : Всесоюз. Обществ. Фонд защиты от безработииь, 1991. - 208 c. /nер. с анг. А. Крылова]. - СПб. : Мидгард, 2008. 349 c. 